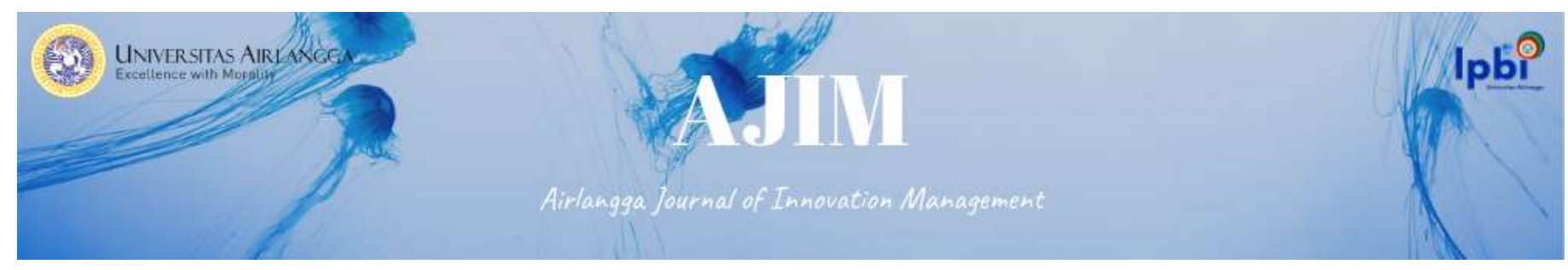

Vol. 1 No.1, June 2020

e-ISSN: 2722-5062

DOI:

\title{
VALUING RECYCLED PAPER WASTE BY THE DESIGN AND MANAGEMENT OF A BOOK COVER MODEL-YRR.18
}

\author{
Jenni Ria Rajagukguk* \\ *Faculty of Technology Management \\ University of Krisnadwipayana \\ Jakarta Indonesia \\ Corresponding e-mail: jenniria rajaguguk@yahoo.com
}

\begin{abstract}
Natural materials are increasingly limited, encouraging the use of materials such as waste materials that have not been widely used for building materials or manufacturing products. Waste paper has been used as a material for the book-YRR.18 book cover through management and design approaches. The waste paper materials used are better than those used to produce this book cover: cellulose $=45.80 \%=$ pentosan $25.90 \%$ and lignin $=22.60 \%$. Therefore, this research aims to provide product design from environmentally friendly materials and analysis of the value of its products in terms of loss-profit, so that it can be a profitable business potential for book producers in Indonesia as well as encourage book producers in Indonesia to being involved in efforts to save the environment.
\end{abstract}

Keywords: Waste Paper Material; Product Value; Design Book Cover Model-YRR. 18.

\section{ABSTRAK}

Bahan-bahan alami yang semakin terbatas, mendorong penggunaan bahan-bahan seperti bahan limbah yang belum banyak dimanfaatkan untuk bahan bangunan atau pembuatan produk. Kertas bekas selama ini digunakan sebagai bahan pembuatan sampul buku Model -YRR.18 melalui pendekatan manajemen dan desain. Bahan limbah kertas yang digunakan lebih baik daripada yang digunakan untuk memproduksi sampul buku ini adalah: selulosa $=45,80 \%=$ pentosan $25,90 \%$ dan lignin $=22,60 \%$. Oleh karena itu, penelitian ini bertujuan untuk memberikan desain produk dari bahan ramah lingkungan dan analisa nilai produknya dari sisi loss-profit, sehingga dapat menjadi potensi bisnis yang menguntungkan bagi produsen buku di Indonesia sekaligus terlibat dalam upaya penyelamatan lingkungan.

Kata kunci: Bahan Limbah Kertas; Nilai Produk; Desain Sampul Buku Model-YRR.18.

\section{INTRODUCTION}

As a result of increasing human activity, millions of tons of waste are produced every day in this world. Waste becomes a serious problem, especially in many cities in the world, due to limited land to dispose of it, bury it and even burn it as conventional waste management. Meanwhile, the population growth is not followed by more effective and efficient waste management. The public is also not fully educated to manage waste based on its type: liquid, solid, organic or non-organic. For examples, solid and non-organic waste that has accumulated is paper waste. The management of paper waste into recycled 


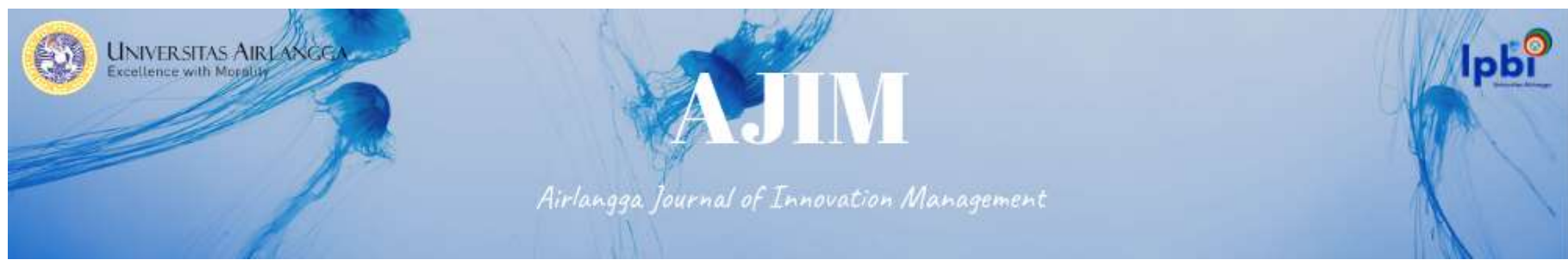

paper has been proven to have high economic value, improving the community's economy, while helping to reduce pollution and cutting down trees for paper making (Arena et al, 2004).

According to Law No. 18 the Year 2008 Article 20 Paragraph (1), Waste Management is conducted by 3R concept: Reduce, Reuse and Recycle. This means reducing the level of demand for trash, reusing rubbish that has been there, and recycling waste bins are used. One of garbage that can be recycled is paper. During this time, paper waste used as wrapping paper, or thrown away, which eventually will contaminate the environment. Although the paper waste, including waste that can be parsed, it takes a long time to be ground. In fact, paper waste can be processed into a variety of interesting craft items, books, and useful cover as well as a high value because it has a beautiful texture. From recycled paper, we can create a wide variety of crafts, where the processing method is also relatively easy, and anyone can do it (Kirkby, 1993). Thus, in addition to minimizing the amount of litter in the environment, improve the community wealth, this study aims to create product design of Book Cover YYR-18 series by using the mixture of paper waste. This study will describe about how the utilization of paper waste and how its selling value based on profit-loss management approach so that it can be a profitable business potential for book producers in Indonesia as well as encourage book producers in Indonesia to being involved in efforts to save the environment.

\section{LITERATURE REVIEW}

\section{The Impact of Waste Paper on Human life}

Paper is a thin and flat material, which is produced by compression of fibers derived from pulp (Satrio \& Kodoatie, 2010). The fiber used is always natural and contains cellulose and hemicellulose. The paper is a new revolution in the world of writing that contributes great significance in world civilization. Before paper was invented, people used burning clay tablets. Paper is known as the main media for writing, printing and painting and many other uses that can be done with paper, for example, cleaning paper (tissue) used for dishes, cleaners or toilets. In general, paper can be divided into two categories, namely the paper and paper industry. culture including culture paper are printed and written papers, such as paper books, books, newspapers, and paper envelopes.

The impact of paper on the environment is negative due to being borne by nature due to the presence of paper waste (Muttaqin, 2011). This impact was very significant. As known, the paper used since ancient times as a primary material to write has now become goods that are integral to human life. Paper made from a raw material tree, to meet human needs for paper, the thousands of trees felled each year, destroying forests are the lungs of the world and also resulted in the scarcity of flora and fauna. Excessive human need for paper resulting in increased production of waste paper in the environment. Although it can be decomposed, but still often found piles of garbage consisting of paper (Muttaqin, 2011).

\section{Benefits of waste paper}

Waste paper has unexpected benefits because it can be recycled into art paper and can be used to make crafts such as greeting cards, cardboard box surface covers, bags, lamp shades. Waste paper processing has been used by many people, often without them knowing it. This business is exciting because it can make new objects something useful of course, with capital that is not too large for the main raw material is used paper. In addition, this business can help the government reduce the volume of waste. (Merrild et al. 2018)

\section{Waste Management of Paper}

Based on Schmidt et al. (2007), paper waste management is the process of turning waste into new materials with the aim of preventing waste that can be useful, reducing the use of new raw materials, reducing usage, reducing energy pollution, land degradation, and greenhouse gas emissions when compared to the manufacturing process new stuff. Processing is one of the solid waste management 


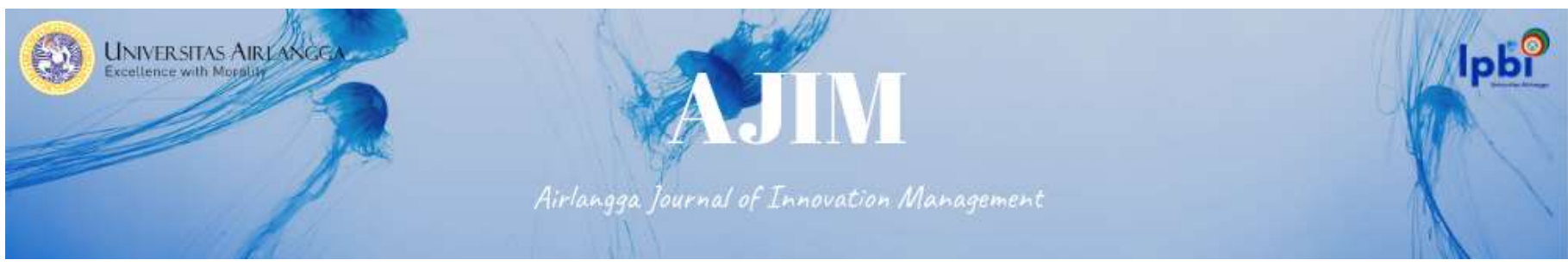

strategies that consists of sorting, collecting, processing, distributing, and manufacturing the products / materials used, and the main components in modern waste management and the third part in the $3 \mathrm{R}$ waste hierarchy process (Reuse, Reduce and Recycling Repeat). Materials that can be processed consist of glass, plastic, paper, metal, textile, and electronic waste. Although similar, the composting process which generally uses biomass debris that can be degraded naturally, is not categorized as processing. Processing is more focused on waste that cannot be degraded naturally for the sake of reducing land degradation. Processing is the process of collecting waste, sorting, cleaning and processing new materials for the production process. Limited understanding, processing must produce goods that are similar to original goods with the same material, for example used paper must have the same quality paper, or polystyrene used foam must be polystyrene with the same quality. But this is often difficult to do because it is more expensive than the process of making it with new materials. Thus, processing is the process of reusing materials into different products. Other forms of processing are extraction of valuable materials from waste, such as gold from computer processors, lead from batteries, or extraction of materials that are harmful to the environment, such as mercury.

\section{Understanding pulp}

Pulp is the separation of fibers from fibrous raw materials (wood and non-wood) through various manufacturing processes (mechanical, semi-chemical) (Mjör, 2009) Pulp consists of fibers (cellulose and hemicellulose) as raw material for paper. The pulping process is carried out by mechanics, chemists and semi-chemists. The principle of making mechanical pulp is by erosion using tools such as grinding. Mechanical processes commonly known include PGW (Pine groundwood), SGW (Semi groundwood). Semi-chemical process is a combination of mechanical and chemical for example CTMP (Chemi Thermo Mechanical Pulping) by utilizing temperature to degrade lignin so that the pulp obtained has a lower yield with better quality than pulp with a mechanical process. The process of making pulp by a chemical process known as the kraft process is to produce pulp that has a higher strength than mechanical and semi-chemical processes, but the yield produced is smaller than both because the components are more degraded (lignin, extractives, and minerals) (Indrawan, 2015).

\section{Method of Pulp Preparation}

Based on Indrawan (2015), pulping is the process of separating cellulose fibers from mixing materials (lignin and pentosan), releasing bulk form into fiber or collecting fiber. Lignin collection must be eliminated because it can make paper pulp degrade. The process of making pulp is of three types:

1. Mechanical method (ground wood) - separation of mechanical fibers - strength and whiteness of paper are not preferred - suitable for newsprint, tissue - 95\% conversion

2. Chemical methods - chemical separation of cellulose separating agents a. Alkaline (soda process and kraft process) b. acid (sulfite process, magnetic process, neutral sulfite process) and the basic selection process: - raw materials used pulp properties - strength and whiteness of paper are preferred - suitable for writing paper (HVS) - conversion of $65-85 \%$

3. Semi-chemical method - a method of mixing chemical softener with a solution of sulfite, sulfate or soda and mechanical fiber separation - type of method: cold soda method and groundwood chemo method - conversion: 85 - 95\%.

\section{The Used Materials: Cellulose and hemicellulose}

According to Ververis et al. (2007), cellulose is a major part of woody plant tissue. The main ingredient is contained in paper plants, but basically, cellulose is found in plant species, including perennial plants, shrubs, and even the simplest vines such as fungi, algae, and mosses. Based on the degree of polymerization (DP) and solubility of sodium hydroxide $(\mathrm{NaOH}) 17.5 \%$, cellulose can be divided into three types: Cellulose A (Alpha Cellulose) is a long chain cellulose, insoluble in $17.5 \% \mathrm{OH}$ 


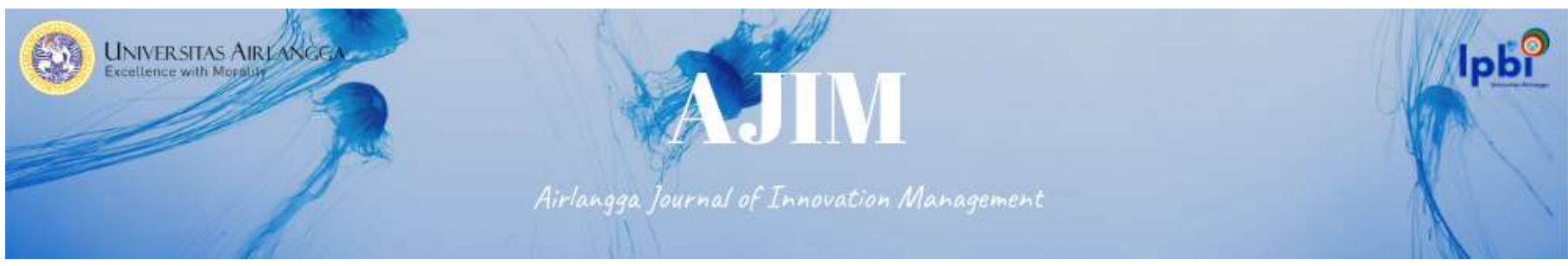

or alkaline solution strong with DP (degree of polymerization) 600 - 1500. Cellulose is used as a predictor or determines the level of purity of cellulose. B cellulose (Betha Cellulose) is a short chain cellulose, dissolved in a $17.5 \% \mathrm{NaOH}$ solution or a strong base with DP 15-90, can settle when neutralized. According to Winarno (1997), $\mu$ cellulose (Gamma cellulose) is the same as $\beta$ cellulose, but the DP is less than 15. $\alpha$ Cellulose is the most high-quality cellulose (mummy). Cellulose $\alpha>92 \%$ qualifies for use as a main raw material or propellant and explosives. Whereas, low quality cellulose is used as raw material in the paper industry and the clothing / fabric (fabric) industry. Cellulose can be compounded (esterified) with inorganic acids such as nitric acid (NC), sulfuric acid (SC) and phosphoric acid (FC). Of the three elements, NC has a strategic economic value rather than sulfuric acid / SC and phosphate / FC because it can be used as a fuel for raw materials / explosives in the manufacture of industrial ammunition / machinery or explosives.

Hemicellulose, a non-cellulose polysaccharide, if hydrolyzed will produce D-MANOVA, D-galactose, D-xylose, D-xylose, L-arabinose and urination acids. Holosefulosa is a part of free fiber and essence and lignin, consisting of a mixture of all cellulose and hemicellulose. Hemicellulose is another polysaccharide contained in plants and is classified as an organic compound, hemicellulose is non-crystalline and nonfiber, easy to expand because hemicellulose is very influential in the shape of the braided fibers when forming sheets, is more soluble in alkaline solvents and is more easily hydrolyzed with acid. The difference between hemicellulose and cellulose is alkali hemicellulose that less soluble in acid. Hemicellulose degradation in acid is higher than delignification and hydrolysis in alkaline conditions is not as easy as acid; Hemicellulose reduces the time and effort needed to soften fibers during mechanical processes in water. Hemicellulose functions as a supporter of cell walls and functions as an adhesive between a single cell contained in a banana tree and other plants. Hemicellulose has non-crystalline properties and is not fiber, is easy to develop, soluble in water, highly hydrofoil, and alkali soluble hemicellulose. The high content contributes to the bond between fibers because hemicellulose acts as an adhesive in every single fiber (Ververis et al., 2007).

\section{Product Design (Principles of Product Design)}




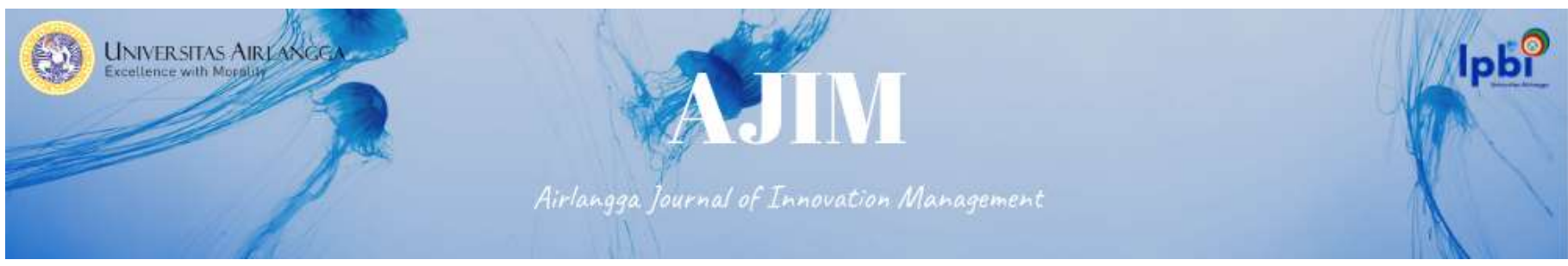

According to Kotler et al. (2015), product design is one aspect of product image formation. There are seven product design parameters, namely: features, performance, quality, suitability, durability, reliability, repairability and style. Book cover products are currently experiencing significant innovation developments, both in material and design. In fact, some have been able to custom disorder (according to consumer demand). This must be considered by producers of textbooks or text to pay attention to design problems, to be able to increase the added value of their products and simultaneously increase sales (Widyokusumo, 2012). This is because before buying a product, consumers often not only consider aspects of functionality, but also aspects of design that suits their lifestyle. In fact, each different market segment has a preference for different types of product designs that book producers should be able to capture as an opportunity.

\section{Value-Based Selling}

Value-based selling strategy (Value-Based Selling) is a sales strategy that prioritizes the value of a product for customers and overrides the price. The main target in this sales strategy is to create value in the product so that customers find answers to the question "why should you use this product". In contrast to price-based sales strategies, where many put forward low prices to be able to sell, this sales strategy can produce sales at prices that are relatively more expensive than prices in the market (Kotler et al., 2015). This is a sales strategy that is usually used to sell products that in the production process require more costs than conventional production processes, so that the impact on the selling price of products is more expensive, but the product provides more benefits / value to consumers. Environmentally friendly products, for example, tend to have higher prices, but give ethical feelings to consumers, because by buying these products, consumers also contribute to making the earth better and more sustainable. This group of consumers is usually called green consumers, who are willing to pay dearly, as long as they consume products that are processed in an environmentally ethical manner (Young et al., 2010). This strategy is suitable to be used to market YRR. 18 model book cover products made from this waste paper.

\section{METHOD}

This research was conducted in East Jakarta Jatiwaringin that explaining the conventional processing of paper waste that collected from household waste. The type of research is field research that carried out for three months from December 5 until February 30, 2018. The method used is a method of study Engineering (Recycling) as explained by Figure 1 below:

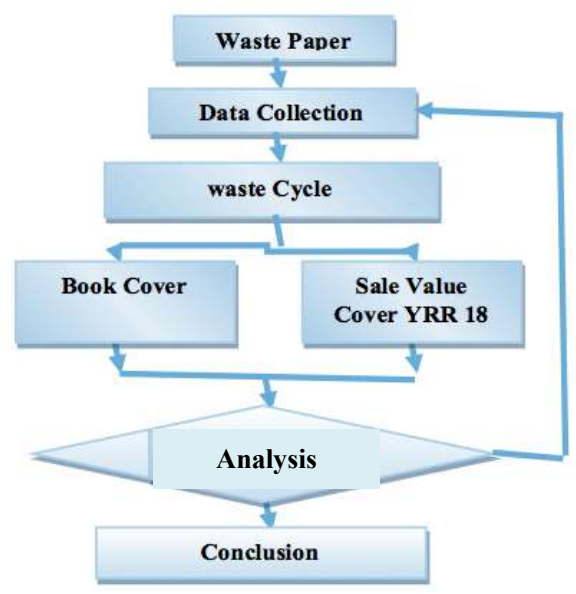

Figure 1. Procedure Research Activities 


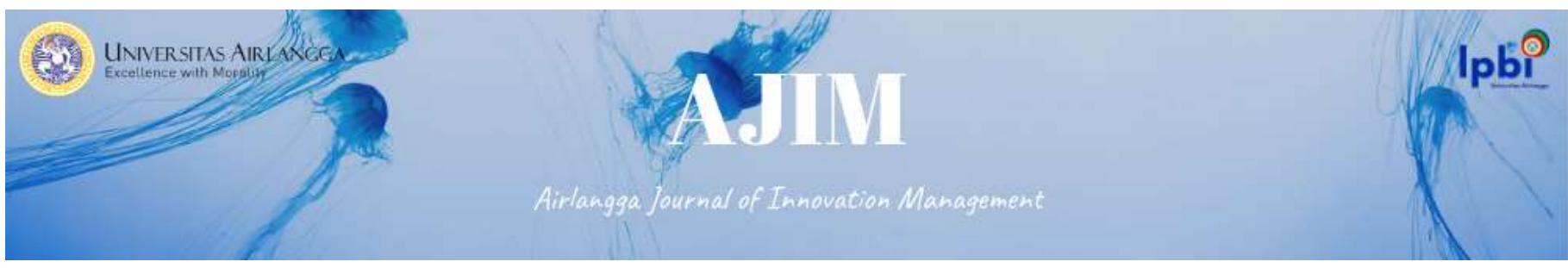

\section{RESULTS AND DISCUSSION}

\section{The Process of Book Making}

The book brand to be designed is the Cover - YRR18 model with a size of $24 \mathrm{~cm} \times 18 \mathrm{~cm}$. The materials used to produce this book cover are: cellulose $=45.80 \%=$ pentosan $25.90 \%$ and lignin $=22.60 \%$. The work steps are as follows:

1. Soak the paper about 24 hours for newsprint, four days for the cover of the book.

2. Soaked paper then blended until smooth like pulp. To conserve water, the filtered pulp is filtered. So the water can be used again for the next blender

3. Mix sago porridge with sago water mixture. This glue keeps the paper from tearing. In this process, sago glue is better than white glue or wood glue. It should be noted that when sago glue is mixed, the pulp should not be left until the next day because the glue will stale on its own. Estimate the dilution level of the pulp mixture, sago glue, and water. Do not get too thick / thin, and can be filtered. If you want color, you can add natural dyes. For example, if you want to give it a yellow color, turmeric is mixed first. Similarly, given green, pandanus leaves are also juiced

4. Now it's time to print. Filter mixture with screen. by soaking the screen into a bowl and then removed with plastic with a lid.

5. Place the board on plastic and rotate it.

6. Drain and flatten with a sweep

7. Lift the screen (if step 10 is dried until it is completely dry, the result is more perfect)

8. Do the drying process and

9. After drying, do the printing process and book bending. 

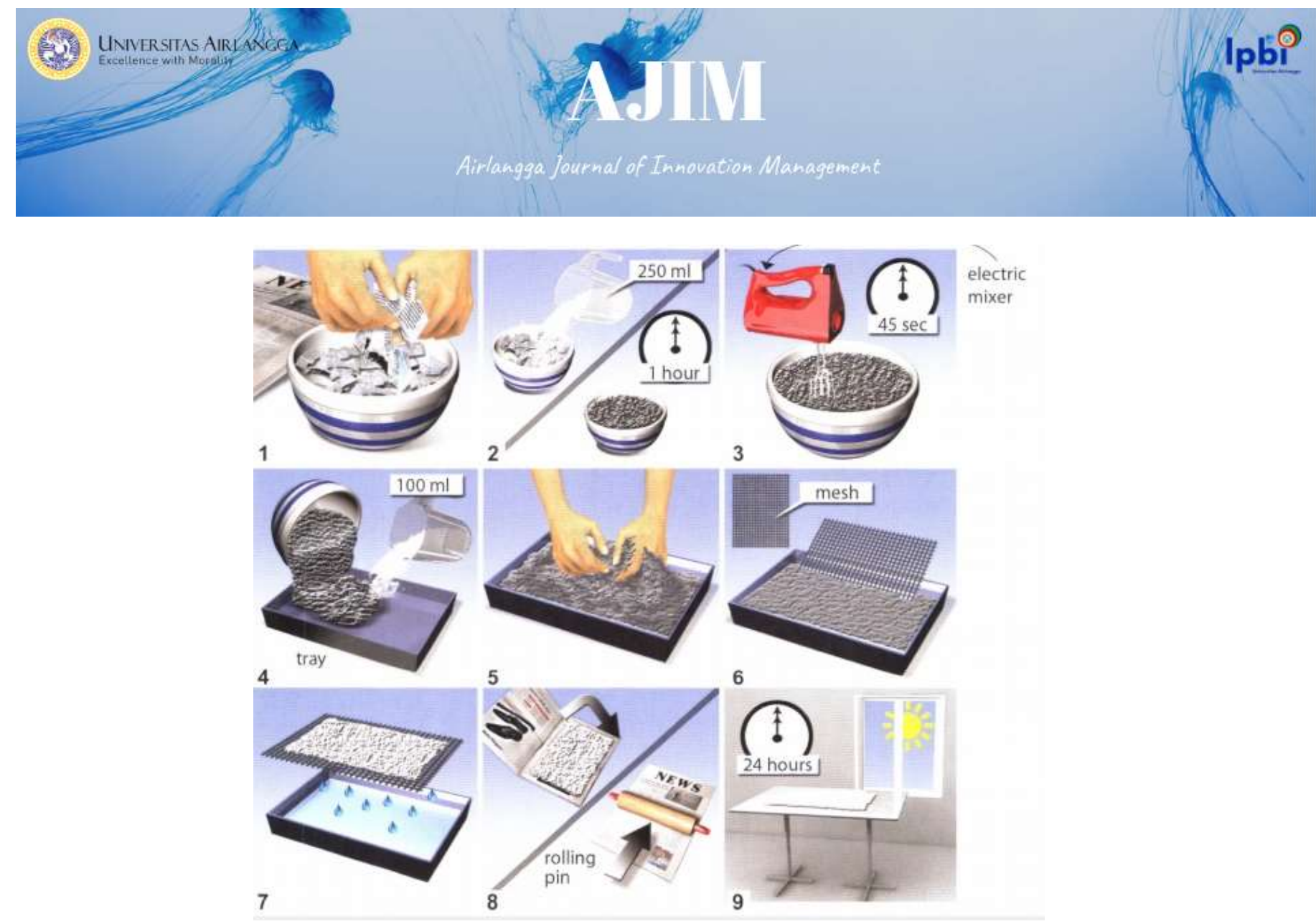

Figure 2 The Book Cover Making Process

Source: illustrated by authors

Figure 3 The Sample Design of Book Cover YRR.18 Model

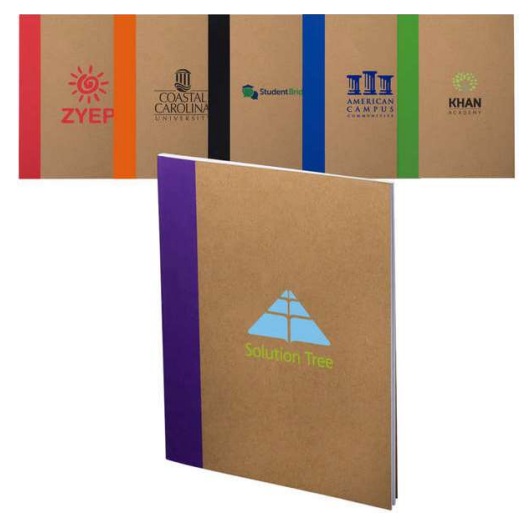

Source: illustrated by authors 


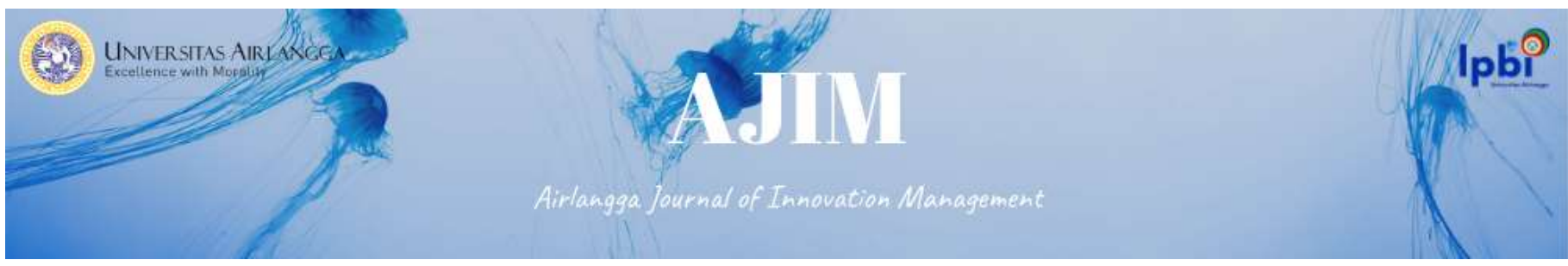

Table 1. Cost Analysis of Book Cover Production

\begin{tabular}{|c|l|r|r|}
\hline A & \multicolumn{2}{|c|}{ income Services } & Cost (Rp) \\
\hline & $\begin{array}{l}\text { Revenue per kilogram } \\
\text { Book Paper }\end{array}$ & & \\
\hline & Rp. 500 x 600 \\
& Income / Month & Operating Costs \\
\hline B & \multicolumn{2}{|c|}{} \\
\hline & 1. Labor 3 & $9,000,000.00$ \\
\hline & 2. Phone & & $3,000,000.00$ \\
& 3. Marketing (Internet & $150,000.00$ \\
& brochure, Pamphlet, etc.) & & $250,000.00$ \\
& 4. Administration & $100,000.00$ \\
& 5. Vehicle (maintenance and & & \\
& fuel) & & $500,000.00$ \\
& 6. Depreciation Vehicle & & $833,000.00$ \\
& (500,000: 60 Months) & & $4,833,000.00$ \\
\hline & total Operations & & $4.166,667,00$ \\
\hline & Net Operating Income & & \\
\hline
\end{tabular}

\section{Source: Estimated calculation by authors}

To start this business, an estimated initial capital of around 5 million rupiah is needed, with details of the purchase of capital goods as described in the table above. The estimated income that can be obtained from the sale of this book cover is to reach 9 million rupiah per month. To achieve this revenue, there are value-based selling strategies that have been implemented to achieve this, namely:

1. Understanding the situation;

2. Defining the problem;

3. Clarifying the short-term and long-term implications of that problem;

4. Quantifying the "need-payoff,"” or the financial and emotional benefits the customer would experience after the resolution of their problem.

Instead of barging in with a premature, boilerplate hard-sell, successful paper producer and seller should focus on asking specific questions to get to the root of what the prospect actually wants. By encouraging your prospects consumers to tell us more about what they need, we reap two major benefits.

First, it increases the prospect's confidence in our understanding of the situation, increasing their trust in our ability to deliver a solution, an alternative of environmentally-friendly paper product. Second, our company will discover information that will help us to emphasize just how valuable our offer is in relation to what they're doing, which helps in framing the price of our offer versus the value it will provide. If our company able to discover why, how, and how much your offer will benefit the customer, we will be able to explain that value in terms they will understand and appreciate. Understanding the value we can provide your customers is the golden path to a profitable sale.

\section{CONCLUSION}

From the analysis and discussion above, this summarizes that, to create a book cover model YRR.18, we better to use raw consisted of cellulose $=45.80 \%=25.90 \%$ pentosan and lignin $=22.60 \%$. Based on the profit and cost analysis, the cost of waste paper able to generate net operating profit for the producer. To maintain the quality of book cover, it is important to measure reliability, durability, and safety in the process of sewage treatment. Furthermore, this study is expected to give contribution for ergonomics study, 


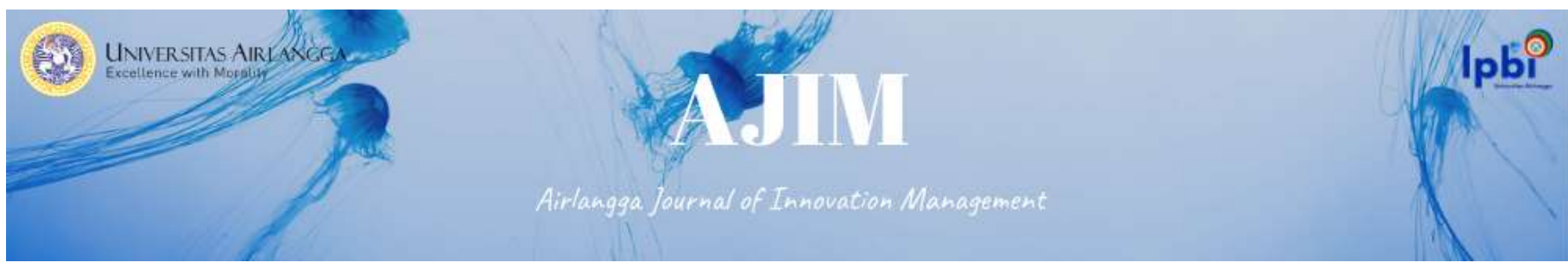

that concern about the inseparable interaction between man and his environment that manifested by product design and management.

\section{REFERENCES}

Alejandro, T. B., Töytäri, P., Alejandro, T. B., Parvinen, P., Ollila, I., \& Rosendahl, N. (2011). Bridging the theory to application gap in value-based selling. Journal of Business \& Industrial Marketing.

Arena, U., Mastellone, M. L., Perugini, F., \& Clift, R. (2004). Environmental assessment of paper waste management options by means of LCA methodology. Industrial \& engineering chemistry research, 43(18), 5702-5714.

Bexley, R. G., \& Thomson, B. S. (1983). U.S. Patent No. 4,377,430. Washington, DC: U.S. Patent and Trademark Office.

Gitosudarmo, I. (1984). Prinsip Dasar manajemen. BFFE

Indrawan, D. A., Efiyanti, L., Tampubolon, R. M., \& Roliadi, H. (2015). Pembuatan Pulp untuk Kertas Bungkus dari Bahan Serat Alternatif. Jurnal Penelitian Hasil Hutan, 33(4), 283-302.

Karwowski, W., Soares, M. M., \& Stanton, N. A. (2011). Human factors and ergonomics in consumer product design: Uses and Applications. CRC Press.

Kirkby, G. (1993). Waste management: three R's (reduce, reuse, recycle) reduce waste, save money. Leadership in health services = Leadership dans les services de sante, 2(2), 30-33.

Kotler, Philip., Burton, Susan, Deans, Kenneth., Brown, Linen and Armstrong, Gary. (2015). Marketing $9^{\text {th }}$ Edition. Pearson Australia.

McCain, W. B., Cosgrove, J. F., \& Zagorski, E. J. (1976). U.S. Patent No. 3,966,185. Washington, DC: U.S. Patent and Trademark Office.

Merrild, H., Damgaard, A., \& Christensen, T. H. (2008). Life cycle assessment of waste paper management: The importance of technology data and system boundaries in assessing recycling and incineration. Resources, Conservation and Recycling, 52(12), 1391-1398.

Mjör, I. A. (2009). Dentin permeability: the basis for understanding pulp reactions and adhesive technology. Brazilian dental journal, 20(1), 3-16.

Muttaqin, Z. (2011). Buku Manfaat Limbah Bagi Kehidupan Manusia.

Papas and Mark Hirshey. (1995). Ekonomi Managerial. Bina Rupa Aksara,Jakarta

Pati, R. K., Vrat, P., \& Kumar, P. (2008). A goal programming model for paper recycling system. Omega, 36(3), 405-417.

Satrio, D., \& KODOATIE, J. M. (2010). Analisis Dampak Investasi Pada Industri Pulp dan Kertas Terhadap Kesempatan Kerja dan Pendapatan Rumah Tangga Indonesia (Doctoral dissertation, UNIVERSITAS DIPONEGORO).

Schmidt, J. H., Holm, P., Merrild, A., \& Christensen, P. (2007). Life cycle assessment of the waste hierarchy-A Danish case study on waste paper. Waste management, 27(11), 1519-1530.

Töytäri, P., \& Rajala, R. (2015). Value-based selling: An organizational capability perspective. Industrial Marketing Management, 45, 101-112.

Ververis, C., Georghiou, K., Danielidis, D., Hatzinikolaou, D. G., Santas, P., Santas, R., \& Corleti, V. (2007). Cellulose, hemicelluloses, lignin and ash content of some organic materials and their suitability for use as paper pulp supplements. Bioresource technology, 98(2), 296-301.

Widyokusumo, Lintang. (2012). Desain Sampul Majalah sebagai Ujung Tombak Pemasaran. Humaniora, A Vol.3 No.2 Oktoober 2012: 637-644

Yen, H. W., \& Brune, D. E. (2007). Anaerobic co-digestion of algal sludge and waste paper to produce methane. Bioresource technology, 98(1), 130-134. 